\title{
INTRODUCTION: DIVERSITY OF NATION-BUILDING IN EAST AND SOUTHEAST ASIA
}

\section{CLAUDIA DERICHS AND THOMAS HEBERER}

The current issue of the European Fournal of East Asian Studies addresses the topic of nation-building. It has been chosen because the term 'nation-building' has been revived, so to speak, in the social sciences as well as in anthropology and history, for several reasons. It has also become a common term these days in the arena of international politics; its notion is positive and clearly distinguished from more 'alarming' terms such as 'nationalism'. In the field of international relations, nation-building has gained a prominent position in the debate on failing or even failed states, conflict management and development theory. It is legitimate to say that nation-building has re-entered the debate, for it had been relegated to the backbenches during the latter half of the Cold War period - at least in the perception of Western observers. In Asia and particularly in the post-colonial nation-states of South and Southeast Asia, however, nation-building has been a constant part of the political agenda since the I95os. The articles in this volume relate to this importance. The Western world turned its eyes back towards nation-building when the great conflict areas of the I9gos, such as Somalia, the Balkans, Afghanistan and lately Iraq, offered a gruesome picture of what state failure and societal fragmentation can mean to the inhabitants of an entity called a nation-state. On an international level, nation-building is currently discussed from an instrumental perspective. As Jochen Hippler points out, nation-building is regarded 'either as a preventive political option to avoid the break-up of the state and social fragmentation, as an alternative to military conflict management, as part of military interventions or as an element of post-conflict policies'. ${ }^{1}$ The instrumental character is obviously emphasised by external observers of processes of nation-building rather than by insiders. The view from within a

1 Jochen Hippler, Gewaltkonflikte, Konfliktprävention und Nationenbildung-Hintergründe eines politischen Konzepts (Violent conflicts, conflict prevention and nation-buildingthe background of a political concept), in Jochen Hippler (ed.), Nation-Building (Bonn: Dietz, 2004), pp. I4-30, here p. I5. 
nation-state is significantly different, because those who have been and still are part of a process of nation-building are more or less directly affected by whatever effort is made to create a national identity. If perceptible as such at all, policies of nation-building are often intertwined with policies of socio-political development. They relate to ideologically loaded notions of integration and to a large extent to measures of state-building. While the concept of the nation-state implies that nation-building and state-building are twin processes, it is important to note that they need not go along with each other at all. Nations without a state, like the Kurds or the Palestinians, and states without a nation, like Afghanistan or Iraq, are ample cases in point to demonstrate the necessary distinction of both processes.

But what exactly do we mean by nation-building? The concept indubitably bears a normative notion in that it alludes to the achievement of an objective: a nation. Ideally, this nation then corresponds to a territory and a set of generally accepted rules, norms and principles. The citizens of the territory are formally bestowed with a nationality and, again ideally, identify themselves with the status of being the nationals of a certain state. The identification with a nation thus requires some sense of belonging and imagination. This is why one of the renowned theorists of the concept of nation in the twentieth century, Benedict Anderson, speaks of the nation as an 'imagined community'. ${ }^{2}$ If the imagined community corresponds to what is defined and administered as the nation-state, the goal of nation-building is, at least theoretically, achieved. In practice, the process reveals itself to be much more difficult than the theoretical reflections suggest. Nationbuilding goes beyond pure implementation of policies and establishment of institutions. Even if the institutions that form the pillars of a functioning state (e.g. bureaucracy, judiciary, civil service and public facilities) are working effectively, a community's national identity may still be shaped in separate affiliations. The Hutu and Tutsi communities in Rwanda, for instance, both feel a sense of national identity that is nurtured by their belonging to a particular ethnic community. Their formal nationality is Rwandan, but we may doubt the fullfledged identification with this status. Empirical research shows that the creation of a national identity becomes more difficult the higher the degree of racial, ethnic, religious or cultural pluralism within a state.

\footnotetext{
${ }^{2}$ Benedict Anderson, Imagined Communities: Reflections on the Origin and Spread of Nationalism (London: Verso, 1983).
} 
From a critical point of view, one may ask why it is necessary to build a nation: hence, why not leave the people with the national identity they have developed over time and simply accept their choice? The question is legitimate, but at the same time it fails to notice the historical dimension of the concept of nation and nationstate. In political history and particularly in the history of international relations, nation-states have taken the place of empires. The era of imperial expansion became gradually superseded by the era of national boundaries, whereby 'national' in this sense already refers to a nation-state with a respective geographical and administrative territory. The forerunners and to a considerable extent also the models of the post-colonial nation-states were the former colonialist states in Europe and North America, be they federalised (e.g. USA) or centralised (e.g. France) entities. While the colonialists were still captured by a primarily past-oriented idea of the nation - stories of national heroism tracing back centuries, national myths and originsthe situation in the post-colonial states was different. ${ }^{3}$ It was futureoriented for comprehensible reasons. As historian Wang Gungwu points out, there was hardly any origin the new nations could refer to:

The first generation of historians [in decolonised Southeast Asia] had enough to do to write the story of national origins, often to meet a teleological need, because they realized that the task of nation-building from scratch was a painful one. Some felt it their duty to delineate the contours of the future by giving a new and greater certainty to their countries' more distant pasts. ${ }^{4}$

Consequently, the 'Western' concept of nation was not considered as matching the post-colonial situation.

$[T]$ he nation-state as a new kind of polity was more alien than most people realized at that time. Learning from Western and Eastern Europe, or Japan, or China or the United States, may have looked easy for the small group of elites who captured power in the postcolonial states, but building a stable and prosperous nation has been much more elusive. ${ }^{5}$

The models taken from Europe were unfamiliar and seemed alien to the people. Not surprisingly, the political leaders in the newly inde-

3 For an outline of these ideas see the compact reader by John Hutchinson and Anthony D. Smith (eds), Nationalism (Oxford: Oxford University Press, I994).

4 Wang Gungwu, 'Introduction', in Cheah Boon Kheng (ed.), Malaysia. The Making of a Nation (Singapore: Institute of Southeast Asian Studies, 2002), pp. xi-xviii, here p. xv.

5 Wang Gungwu, Introduction, p. xiv. 
pendent nation-states 'who advocated using these models often had great difficulty explaining why any one of them should be adopted'. ${ }^{6}$ They were advocated, however, because there was no alternative in sight - no alternative to guarantee political and social stability, and no alternative in terms of the development of a functioning state apparatus that could actually control its national territory. Nation and nation-state had become synonyms for the achievement of stability, development, modernity and prosperity. And since the nation-state had been consolidated globally as the object of reference for independence and sovereignty, nobody within the political world would have questioned the sense and importance of it. Until today, the concept of the nation-state has not lost its appeal, despite processes of globalisation, supranational institution-building on a regional level (European Union) and increasing transnational cooperation. The task of nationbuilding is as modern and up to date as can be for those states who have gained independence only recently (e.g. East Timor) as well as for those who have been wary of their independent status ever since (e.g. China).

Nation-building today stands for the intention to produce and preserve national cohesion, and in this sense it contains components of strategy, mobilisation, acceptance and appeal. ${ }^{7}$ At an ideological level, the process involves many of the elements that can also be observed in economic production circles. The main difference, however, lies in the fact that the product - 'nation' - is not physically tangible, visible or perceptible; rather, it comprises ideas that are meant to appear plausible to the 'buyers' and which they would prefer to other ideas. National cohesion must be a product that clearly surpasses the idea of separation in a divided state. Delivering the ingredients for the product design - the recipe for national identity, so to speak - is essentially the task of the government. It is responsible for spreading the 'national' idea among society because only it has the possibilities, via the central administrative machinery, to disseminate its ideas throughout the entire country in a controlled manner - with the help of the media, of course. It is quite obvious that there are organisations with competing nation-building recipes aside from the government. The government must stand its ground against these by way of better proposals (ingredients), clearly pointing out that it receives its legitimacy precisely from those to whom it is now submitting its policy. As the

\footnotetext{
6 Wang Gungwu, Introduction, p. xii.

7 The following thoughts draw on Claudia Derichs, 'Die Nation gestalten-Ideologische Aspekte des Nation-Building' (Shaping the nation-ideological aspects of nationbuilding), in Hippler, Nation-Building, pp. 69-87.
} 
representative of the people, the government can conceive of nationbuilding as a political mandate.

Different historical, economic, social, as well as domestic and foreign policy conditions apply in each state for initiating, continuing or concluding a nation-building process. ${ }^{8}$ Even in clearly 'established' nations like France, England and Germany, it is still necessary to foster the national consciousness via a large number of different mechanisms of symbolic integration which go far beyond the flag and national anthem and include economic, sporting, political, historical and other elements. It is therefore questionable whether and when we can talk of an actual conclusion of nation-building. Furthermore, nation-building cannot be analysed by recording 'the state of the nation' at a certain point in time because a nation is a dynamic phenomenon and is therefore subject to constant change. Not least of all, the population itself has to be motivated to become involved in creating, supporting and shaping the nation. The concept of the nation therefore needs to be credible in different respects. It should occupy a central position among the political needs of the target groups (i.e. the citizens), have adequate scope (i.e. also play a role in the day-today life of the population), be linked to important issues on the public agenda (e.g. different policy areas), relate to the experiences of the target groups (e.g. incorporate traditional forms of social organisation), arouse narrative intimacy (i.e. have recourse to a cultural repertoireliterature, art, rituals, etc.-familiar to the people) and be simultaneously flexible and open to change.

If we remain with our succinct image of ideological nation-building as an economic transaction, the prognosis that 'everyone will be better off' if there is national cohesion will then become a product that the government as a vendor will offer to its people as a selected customer. This is an item that is not always easily available by virtue of its being a product that requires the cooperation of the customer before it can be made into 'what is stated on the label'. Rather, it makes nation-building an interactive undertaking in a value-added process, the end-product of which has a name and vague contours but still lacks a specific shape.

8 The process-type nature of nation-building cannot be overemphasised. One of the most apposite comments made in this regard comes from Walker Connor: 'The delay - stretched out over centuries in some cases - between the appearance of a national consciousness among those belonging to the elite and the spreading of this among the population at large reminds us of the evident but all too frequently ignored fact that nation-building is a process, and not a phenomenon or an event.' See Walker Connor, 'When is a nation?' Ethnic and Racial Studies, Vol. I3, No. I (I99o), pp. 92-IOo, here p. 99 f. 
The actuality of nation-building in today's world spans regions and continents. In Northeast, Southeast, South and Central Asia we find old nations, young nations and yet-to-be-built nations alike. Most of the nation-states in Asia have to cope with various racial, ethnic, cultural or religious nationalities within their boundaries. This makes Asia a particularly interesting region for research on nation-building.

\section{Nation-building in East and Southeast Asia}

In fact, most states in East and Southeast Asia are multi-ethnic states, partially coined by vehement ethnic conflicts and internal colonialism, i.e. the enlargement of the settlement area of the dominant ethnic group by means of the state under its control. In socialist countries like China or Vietnam, strong single-party states, representing the interests of the ethnic majority, attempted to enforce ethnic assimilation. Until the early ig8os all ethnic particularities were suppressed. Although more liberal nationalities policies have been adopted since then, the rigid policies relating to ethnic and religious issues stirred up conflicts between the party-state and some of its larger nationalities.

Indonesia, where at least 30 larger ethnic entities are living, officially speaks merely of 'Indonesians', thus denying in principle the existence of ethnic minorities - despite the slogan of 'Unity in diversity'. Ethnic unity is enforced by means of a uniform language (Bahasa Indonesia) and by proclaiming the existence of but one homogeneous nationality (Indonesians). Large-scale resettlement programmes under which Javanese people migrated into the outer islands and economic discrimination became the reasons for major conflicts (e.g. in Aceh or Irian Jaya). Myanmar to this day utilises military power to wipe out all modes of independence or autonomous endeavours of its ethnic minorities. Yet all these 'hard' policies have proved to be unsuccessful.

Although in Thailand the 'mountaineers' were endowed with Thai citizenship in 1974, the lingering conflict between the ethnic Malay Muslim minority in the southern part of the country and the Buddhist Thai state continues to create tension. In the Philippines, in turn, parts of the Muslim minority is challenging the state of the Christian majority, perceiving its living space to be threatened by the Christian majority due to the in-migration of Christians and a perception of economic inferiority.

Yet concurrently there are rather positive developments too. In Malaysia, for instance, where conflicts between the Malay majority and a strong Chinese minority were prevalent until the I980s, con- 
flicts have decreased since the I99os, although the constitution defines Islam as the religion of the state and Malay language (Bahasa Melayu) as the national language. ${ }^{9}$

In the various countries different ethnic constellations can be discerned as, for instance,

- nationality-states that emerged over the course of history through the incorporation of several major nationalities by means of enlarging a country's territory (called empire-building) (e.g. China, Vietnam, Thailand);

- multi-ethnic states created by territorial borders drawn by colonial powers without consideration of ethnic boundaries, and in which subgroups of different nationalities live (Indonesia, Myanmar);

- states that have become multinational states through peaceful immigration (as in Singapore or Malaysia).

In contrast to many African states, states in East and Southeast Asia exhibit various distinct features:

- Many of those states already existed in pre-colonial times (China, Vietnam, Thailand, Cambodia, etc.).

- Within the various countries we find multiple cultural commonalities - a crucial precondition of modern nation-states.

- The emergence of development-oriented political elites gradually led to a pattern of a 'soft authoritarianism'.

- Strong nationalist movements have a major impact upon politics.

- The dominance of authoritarian patterns was harnessed to enhance the autonomy and capacity of the state.

${ }^{9}$ Overviews on ethnic minorities issues and nationalism in East and Southeast Asia are provided in: Gehan Wijeyewardene (ed.), Ethnic Groups across National Boundaries in Mainland Southeast Asia (Singapore: Institute of Southeast Asian Studies, I990); R.H. Barnes, Andrew Gray and Benedict Kingsbury (eds), Indigenous Peoples of Asia (Ann Arbor: Association for Asian Studies, 1995); Don McCaskill and Ken Kampe (eds), Development or Domestication? Indigenous Peoples of Southeast Asia (Chiang Mai: Silkworm Books, 1997); Thomas Engelbert and Andreas Schneider (eds), Ethnic Minorities and Nationalism in Southeast Asia (Frankfurt/M.: Peter Lang, 200o); Robert W. Hefner (ed.), The Politics of Multiculturalism. Pluralism and Citizenship in Malaysia, Singapore, and Indonesia (Honolulu: University of Hawai'i Press, 200I); Thomas Engelbert and Hans-Dieter Kubitschek (eds) Ethnic Minorities and Politics in Southeast Asia (Frankfurt/M.: Peter Lang, 2004); Christopher R. Duncan (ed.), Civilizing the Margins. Southeast Asian Government Policies for the Development of Minorities (Ithaca: Cornell University Press, 2004); Claudia Derichs, Nationenbildung in Malaysia als strategisches Staatshandeln. Bemühungen um die Schaffung nationaler Identität (Nation-building in Malaysia as Strategic State Action. Efforts towards the Creation of National Identity) (Hamburg: Institut für Asienkunde, 2004); Hiroko Yokoyama (ed.), The Dynamics of Cultures and Society among Ethnic Minorities in East Asia (Osaka: National Museum of Ethnology, 2004). 
The majority of the states in East and Southeast Asia (except Thailand, China and Japan) previously had been under colonial rule. Following independence, some of the new states were established on the basis of artificial boundaries which had been drawn by colonial powers and of multi-ethnicity (Indonesia, Malaysia, Myanmar, etc.). Therefore, state-building had to be followed by nationbuilding.

The differences between various countries engendered different concepts of nation-building. The dominant pattern in most of the states was to reinforce the authority of the state, combined with attempts at a more or less enforced assimilation of ethnic minorities. Glifford Geertz has called this 'integrative revolution', i.e. the absolute integration of ethnic minorities into the new states, or even assimilation. As such a policy evoked violent ethnic conflicts, most countries in the r 980 s shifted to a more moderate strategy of a soft nationalities policy. This shift resulted in a de-ethnicisation of politics with more subtle patterns of cultural assimilation.

Concurrently, the political elites attempted to create a shared national consciousness by means of ideological patterns. 'Chinese', 'Vietnamese' or 'Burmese' socialism, Singapore's 'National Ideology', the Indonesian concept of Pancasila, the Malaysian Rukunegara or the Melayu Islam Beraja of Brunei imply an overarching and integrating function. Strikingly, there are strong commonalities between those ideological concepts, such as an imagined solidarity between different ethnic groups within a given country, development on the basis of equality and assuring a minimal basic living standard for every citizen; a consensus principle in political discourses; ensuring popular welfare by the state; exclusion of parallel political power structures; the perception that the state (or the leading party) is representing the nation, thus identifying the state with the nation (state nationalism); and the integrative function of the military within the nation.

Here, society is perceived as an organic unity and the state as an embodiment of the interests of this imagined entity. The task of the state is to enforce or preserve this unity and thus the concept of nation-building. That is why authoritarian states in East and Southeast Asia in the name of preserving national unity and stability attempt to eradicate particularising interests of single social or ethnic groups, and to prevent political contest and the formation of parallel power structures.

Subsequently, nation-building in East and Southeast Asia is still an expression of a state-induced nation-building, in which states more strongly employ material incentives (economic and financial ones), 
cultural incentives (language policy, educational system, religious policy, etc.) or pressure. ${ }^{10}$ Developmental processes in East and Southeast Asia reveal the crucial role of the state and development-oriented elites, even in terms of the military or a single-party rule. Governance, understood as the exertion of power in the interest of national development, and the corresponding successes of both development and modernisation in the region appear to give evidence to the argumentation of authoritarian political elites, as in China or Vietnam, that strong authoritarian developmental states are to function as a driving force of development. This is why nationalism in East and Southeast Asia is less an aggressive, externally oriented ideology but rather entertains domestic functions. Here, nationalism currently implies two major functions. First, it functions as an integrative nationalism aiming at further state- and nation-building. Second, it works as a modernisational nationalism, designed to mobilise the people in the interest of a shared goal: modernisation as a 'solidarity vision' for the nation. Having said that, it is obvious that the Taiwan issue is not an indication of a growing external, aggressive behaviour, as China perceives Taiwan as an internal affair. Therefore, the Taiwan issue has to be comprehended rather as an issue of nation-building and thus of an integrative nationalism.

Furthermore, the character of nation-building is strongly related to the capacity of a state. And, in fact, state capacity is more developed in strong states such as Singapore or Malaysia than in weak ones like Myanmar or Laos. Different types of nation-building in the region derive from various concepts of nation that the dominant ethnic majority adheres to. They are strongly related to the given political system, the extent of ethnic tensions, the degree of ethno-nationalism within a country, the equality or inequality of citizens, and to the question of whether the state represents the interests of the entire citizenry or merely those of the dominant ethnic group.

Certainly, nation-building is a salient task of the state. But if it is perceived to be the task of the state only, the outcome might be an authoritarian political system. On the one hand we have to decouple state and nation, even more so as the state does not constitute a community but rather a legal and political concept. On the other hand nation-building will have to involve the people and to pay attention to ethnic, regional and local peculiarities. The term 'nationstates', writes Migdal, 'implies that the people are more than mere

\footnotetext{
${ }^{10}$ Jochen Hippler, Gewaltkonflikte, Konfliktprävention und Nationenbildung, p. 24.
} 
subjects; they are participants in constituting and maintaining the state. ${ }^{11}$ And this, in turn, requires democratic structures and policies, something which is not yet self-evident in the region concerned.

Brown distinguishes between the political nation in which 'the state claims that its people constitute a nation because they have willingly come together to form a community of equal citizens irrespective of their racial, religious or linguistic backgrounds' and the cultural nation as 'the community which constitutes a distinct people with its own language, way of life, history and homeland'. ${ }^{12}$ The former is grounded in a shared will to constitute a nation based upon equal rights for all citizens; the latter is based on the willpower of the dominant ethnic group attempting to enforce its culture vis-à-vis the other groups and to perceive the entire society as an ethnic community. In the latter case the culture of a nation is identified with the official culture of the 'state'. As a rule, the dominant group pretends to be the head of the 'ethnic family' whereas the 'ethnic minorities' constitute the children who have to be loyal and obedient to the pater familias. This leads to a strong hierarchisation of the various nationalities in a given country and, therefore, to the devaluation of the 'minorities'. Hierarchisation does not only perpetuate and legitimise inequality and tutelage, but also poses a threat to the people whose culture is devaluated. Hierarchies, according to Michael Walzer, are never 'innocent', because they tend towards policies of discrimination. ${ }^{13}$

As far as nationalism is concerned, we have to differentiate between two patterns: state nationalism and ethno-nationalism. In East and Southeast Asia we find both, frequently intermingled. On the one hand we can discern the assertion that all citizens of a given country possess equal rights; on the other hand the nation is defined by means of distinct cultural terms (Buddhism in Thailand, Islam and Bahasa Melayu in Malaysia, Bahasa Indonesia in Indonesia, etc.). According to Brown it is precisely this contradiction which 'hinders the effective management of ethnic-state relations' and thus an efficacious nationbuilding. ${ }^{14}$ It is the dominant ethnic group and its political elite that pass off their values and their concept of development as those of the entire nation, arguing that these are in the interest of political cohesion, integration and societal loyalty.

\footnotetext{
${ }^{11}$ Joel S. Migdal, 'State building and the non-nation-state', fournal of International Affairs, Vol. 58, No. I (Fall 2004), p. 22.

12 David Brown, The State and Ethnic Politics in Southeast Asia (London: Routledge, I996), p. 26o.

${ }_{13}$ Michael Walzer, Lokale Kritik - globale Standards (Local Criticism-Global Standards) (Hamburg: Rotbuch Verlag, I996), p. I86.

14 David Brown, The State and Ethnic Politics in Southeast Asia, p. 26r.
} 
For many years, social scientists held the opinion that with both economic development and modernisation, religious, ethnic and cultural differences between societies would disappear; ethnic de-differentiation would be the result of modernisation processes. ${ }^{15}$ It was widely assumed that market expansion, industrialisation and modernisation would lead to an ethnic homogenisation of cultures. But in fact the opposite was the case: ethnic revival, social and cultural differentiation, cultural fragmentation, and fragmentation of identity and loyalty emerged as new challenges to nation-building and the nation-state. This is true also for Southeast Asia and China. On a global scale, globalisation generated two simultaneous processes: first, efforts by national governments to maintain control and sovereignty, and second, demands by distinct ethnic groups to preserve their ethnic differences, ethnicity and multiple belongings that are to be accepted within a given national community.

The current issue of the European Fournal of East Asian Studies relates the above-mentioned thoughts to four case studies. We selected a socialist multi-ethnic country which passes through a process of economic and social transformation (China), a multi-ethnic state characterised by both a strong Islamic majority and a significant centreperiphery relationship (Indonesia), a nation defining itself by means of distinct cultural terms (Buddhism, Thailand), and a new state facing a double task of nation- and state-building (Timor-Leste).

Magnus Fiskesjö addresses the issue of Chinese nation-building in the twentieth century. He argues that China had to choose from three options: first, to grant independence to non-Chinese peoples; second, to enforce their assimilation; and third, to incorporate them into a new version of an imperial project. China, so the argument goes, followed the third pattern, endeavouring to transform 'barbarians' into 'minorities'. The reason for choosing this pattern is on the one side related to a 'romantic' and idealising narrative: delightful minorities of prodigy, exoticism and esotericism. On the other side, the historic-materialistic concept according to which the societies of all nationalities in history were classified into the categories of primitive, slave, feudal, capitalist and socialist societies fitted well into the traditional Chinese thinking of hierarchisation. Subsequently,

${ }_{15}$ M. Banton, Race Relations (London: Tavistock Publications, I967), p. 2; H. Esser, Aspekte der Wanderungssoziologie. Assimilation und Integration von Wanderern, ethnischen Gruppen und Minderheiten (Aspects of the Sociology of Migration. Assimilation and Integration of Travellers, Ethnic Groups and Minorities) (Darmstadt: Luchterhand, I980), pp. I I8- I Ig; Friedrich Heckmann, Ethnische Minderheiten, Volk und Nation (Ethnic Minorities, People and Nation) (Stuttgart: Enke, I992), pp. 30-36. 
every ethnic group had its fixed place in the hierarchy of nationalities and in its relationship with the 'most advanced' people, the Han. Under socialism the Han could retain their traditional position and function towards non-Han people: as the societies of the national minorities were considered inferior to that of the Han, the culture of the Han remained the highest-ranking. It was the duty of the Han to civilise and modernise the minorities' societies. The duty of every nationality was to catch up with the Han as quickly as possible and to bring its economy and society into line with that of the Han. Fiskesjö concludes that the 'minority nationalities' are indispensable in order to rescue the empire. Even if they were fully assimilated they would have to be reinvented once again.

With reference to Indonesia's becoming a nation-state, Johan Meuleman uses a historical approach to analyse the country's highly complex and long-term process of nation-building. By tracing the historical roots of Indonesian identity, he points to the fact that subnational and transnational frames of identity-building preceded the national ones - a perspective that is frequently neglected when the focus lies on Indonesia after independence. He draws particular attention to the role of religion and the relations between centre and periphery (i.e. Java and the outer islands) in the process of nation-building during the Soekarno, the Soeharto and the postSoeharto periods. An important observation in this regard is the shift of Islam's position as a religion to that of an element of the cultural field during Soeharto's New Order regime. By dragging Islam away from the political field, Meuleman argues, 'religion should provide the indispensable spiritual and moral framework of economic development'. Islam re-entered politics in the Reformasi era. Although religion has been a 'conspicuous component' of communal conflict, none of the officially acknowledged confessions in Indonesia has been the exclusive or fundamental motive for it. In respect to the process of nation-building, religion as well as ethnicity has had multiple effects on the shaping of a national identity. These effects vary according to specific circumstances and have thus to be looked at within their special, ideological and historical context.

Whereas the articles on China, Indonesia and East Timor attend predominantly to governmental or state-led activities in nation-building, Rüdiger Korff's observations in Thailand refer entirely to the perspective of the country's minorities and their being differently affected by policies that provide or lack care for local communities' demands. Korff's comparison of the situation in the northern and the southern provinces reveals the huge difference of those regions in terms of ethnic composition and desire for independence from Bangkok. The 
development agenda of prime minister Thaksin Shinawatra included a CEO style of provincial administration, which became particularly detrimental to national integration. In contrast to the south, violent resistance to the central state is absent in the north. Korff relates this, among other reasons, to different elite formation in both regions. A more articulated and consequent recognition of the country's minorities would, however, promote national cohesion in north and south alike.

Andre Borgerhoff touches upon Timor-Leste's nation-building. This nation emerged as a new nation-state in 2002, from a Portuguese colony to an Indonesian province, and finally to an independent nation-state. This 'nation of fate' was sparked by the East Timorese common resistance towards Indonesia's campaign to Indonesianise this country. As a former 'nation without a state' Timor-Leste faced a twofold task: nation-building and state-building. Concurrently, both ideological nation-building and pragmatic concerns of state-building have been partially contradictory. In his article Borgerhoff differentiates between nation-building as a set of deliberate strategic policies and actions of political players and, second, as an emerging process. He focuses on two policy domains, education and economic development policies, to underscore his arguments. Finally he concludes that Timor-Leste despite its multi-lingual and multi-ethnic diversity, has successfully emerged as a nation-state.

We hope that this issue will provide new insight into nation-building processes in East and Southeast Asia.

University of Duisburg-Essen, Political Science/East Asian Studies claudia.derichs@uni-due.de, heberer@uni-duisburg.de 
2006008. EJEAS 5.1. Proef 5. 14-7-2006:10.49, page 14 . 